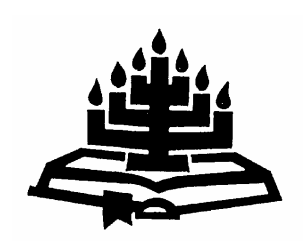

\title{
Om in die Gees te begin en in eie krag te eindig - die noodsaak van 'n Skrif- gefundeerde prakties-teologiese Pneumatologie
}

\author{
F.W. (Fritz) de Wet \\ Skool vir Kerkwetenskappe \\ Potchefstroom-kampus \\ Noordwes-Universiteit \\ POTCHEFSTROOM \\ E-pos: kwsfwdw@puk.net
}

\begin{abstract}
Starting in the Spirit and ending in own power - the necessity of a Scripturally founded practical-theological Pneumatology

In this article one of the main problem areas of Practical Theology is addressed: In the hermeneutical interchange between theological reflection on the normative elements flowing from the revelatory presence and acts of God on the one hand, and ministering these normative elements in the concrete praxis in which man finds himself on the other hand, Practical Theology as discipline may commit the error to start in the Spirit but end in own power. In its core this problem manifests as a lack of a Pneumatology that describes and enhances the true relationship between the Spirit of God and the spirit of man. The need for a practical-theological Pneumatology that operates in the context of the covenantal relationship in which Christ fulfils the role of Mediator is argued and illustrated. The Holy Spirit leads the believer in a relation to praxis that is based on faith in Jesus Christ - seeing reality through his eyes and acting according to his mindset and power. The implications of this kind of Pneumatology are indicated for two important practical-theological aspects: firstly the ministering of reconciliation as the heart of all practicaltheological activity, and secondly the key concept of perception by faith in combining vision of God with vision of what is seen and done in the concrete dimension of the praxis.
\end{abstract}


Opsomming

Om in die Gees te begin en in eie krag te eindig - die noodsaak van 'n Skrifgefundeerde prakties-teologiese Pneumatologie

In hierdie artikel kom een van die groot probleemareas van Praktiese Teologie aan die orde: in die hermeneutiese wisselwerking tussen teologiese nadenke oor die normatiewe elemente wat voortvloei uit die teenwoordigheid en handelinge van die openbarende God en die toepassing van hierdie normatiewe elemente in die konkrete praksis waarin die mens homself bevind, kan dit gebeur dat Praktiese Teologie in die Gees begin maar in eie krag eindig. Hierdie probleem het ten diepste te doen met 'n gebrek aan 'n Pneumatologie waarin die ware verhouding tussen die Gees van God en die gees van die mens omskryf en uitgeleef word. Die noodsaak van 'n praktiesteologiese Pneumatologie wat funksioneer in die konteks van die verbondsverhouding waarin Christus as Middelaar optree, word beredeneer en geïllustreer. Die Heilige Gees lei die gelowige in 'n benadering tot praksis met geloof in Jesus Christus as fondament: Die gelowige sien die werklikheid deur die oë van Christus en tree in sy gesindheid en krag op. Die implikasies van hierdie Pneumatologie vir twee belangrike prakties-teologiese aspekte kom aan die orde: Eerstens raak dit die bediening van versoening as die wese van alle praktiesteologiese handelinge. Tweedens raak dit geloofswaarneming as sleutelkonsep in die koppeling van die visie van God met die visie van dit wat gesien en gedoen word in die konkrete werklikheidsdimensie van die praksis.

\section{Oriëntering: die hermeneutiese wisselwerking tussen normatiewe en konkrete werklikheid}

Praktiese Teologie as teologiese wetenskap funksioneer altyd in die kragveld van die bipolêre verhouding tussen die normatiewe (soos dit uit Skrifopenbaring voortvloei) en die inrigting van die normatiewe in die sigbare werklikheid (Kruger \& Venter, 2001:557). Venter (1996:25) omskryf die ondersoekveld van Praktiese Teologie as die nagaan van kommunikatiewe handelinge in die Skrifopenbaring en die normatiewe, konkrete bediening daarvan in die kerk. In hierdie werklikheid is daar twee refleksiedomeine aanwesig, naamlik

- kommunikatiewe handelinge in die opskrifgestelde openbaring en

- kommunikatiewe handelinge in die konkrete bediening daarvan in die kerk. 
In teorievorming word ten opsigte van die eerste refleksiedomein basisteoreties te werk gegaan en in die tweede refleksiedomein vind praktykteoretiese teorievorming plaas. Hierdie twee refleksiedomeine het met een werklikheid te doen. Om te kom tot praktiesteologiese teorievorming moet die twee refleksiedomeine in ' $n$ hermeneutiese wisselwerking met mekaar gestel word. Venter (1996:26 e.v.) beklemtoon egter dat Praktiese Teologie in die proses van wisselwerking nooit van sy teologiese aard en normatiewe fundering ontneem mag word nie. Pieterse (1993:201) gee 'n belangrike kriterium vir hierdie hermeneutiese wisselwerking wanneer hy - in aansluiting by Habermas se rasionaliteitsmodel vanuit die veronderstelling werk dat normatiewe elemente in alle praksis funksioneer. Praksis word deur norme gerig. Waardes speel ' $n$ rol in die perspektief wat die navorser op sy objek van studie het. 'n Navorser se basisteorie bepaal die perspektief waarmee na die werklikheid gekyk word en gee rigting aan 'n soeke na verandering of grensverlegging van die bestaande sosiale werklikheid.

\subsection{Twee refleksiedomeine, maar één werklikheid}

Dit is juis in die inrigting van hierdie hermeneutiese wisselwerking tussen twee refleksiedomeine waarin met een werklikheid te doen gekry word, en waarin een van die groot probleemareas van prakties-teologiese wetenskapsbeoefening na vore kom. In die hermeneutiese wisselwerking tussen die basisteoretiese refleksiedomein (met as refleksiefokus die onsigbare dimensie van die normatiewe en die bepalende en voleindigende invloed wat dit op die sigbare werklikheid het), en die praktykteoretiese refleksiedomein (met as refleksiefokus die sigbare en konkrete praktyk van die kerk en die manier waarop hierdie praktyk altyd gereformeer moet word) word die wesenlike gevaar geloop dat daar in die Gees begin kan word en in eie krag geëindig kan word (Gal. 3:3). In basisteorie kan in die Gees begin word, maar dit wat uiteindelik in die konkrete werklikheid van praktykteorie geformuleer word en realiseer, spreek van eie krag, kreatiwiteit, innovering en vaardigheid. Sonder 'n dubbele benadering waarin sowel die mens in sy konkrete praksis gesien word (deur middel van 'n verskerpte en verantwoorde antropologiese blik) en God ook in die geloof gesien word (deur middel van 'n outentieke teologiese instelling) (vgl. Immink, 2003:185), gaan die organiese verband tussen dit wat God doen en dit wat die mens doen verlore. Dit wat as verskillende dimensies van een werklikheid gesien behoort te word, dryf as twee losstaande werklikhede uitmekaar. 


\subsection{Goddelike realiteit en menslike realiteit}

Heitink (1999:193) identifiseer die sentrale probleem waarmee Praktiese Teologie te doen het as die hermeneutiese vraag na die manier waarop Goddelike realiteit en menslike realiteit met mekaar verbind kan word op ervaringsvlak. Volgens Pieterse (2005:78) het daar in die Westerse postmoderne geestesklimaat 'n sterk antroposentriese gees ontstaan waarin die mens die maatstaf van alles is. Die goddelike werklikheid verdwyn al meer uit die denkwêreld van vandag se (Westers-georiënteerde) mense.

Hierdie probleem het ten diepste te doen met 'n prakties-teologiese Pneumatologie wat stol in die metafiese en die onsigbare. Op hierdie wyse word die potensialiteit van die Pneumatologie geïsoleer van die konkrete dimensie van die werklikheid. Vos (1996:11) wys daarop dat die skeiding tussen teologie en spiritualiteit noodlottig is: So 'n skeiding veroorsaak dat teologie abstrak word; so 'n teologie gee klippe, terwyl brood nodig is. Ook loop hierdie tipe teologie die gevaar om in blote sentimentaliteit te ontaard. Al word daar met die Gees begin, vervaag die Gees se teenwoordigheid en kragtige optrede tot stippellyne wat al hoe dowwer word namate die dimensie van die sigbare en konkrete werklikheid in die hermeneutiese wisselwerking betree word. In die hermeneutiese wisselwerking tussen normatiewe en konteks, kan ideologiese verstarring plaasvind of utopistiese werklikheidsvreemdheid intree en die verbintenis met die praksis sodoende losgemaak word (vgl. Dreyer, 2002:6). Landau (1981:191) identifiseer die feit dat God ondergeskik gemaak word aan menslike wetmatigheid (antroponome subordinasie) as die oerskuld van die kerk: "Gott wird den Menschen untergeordnet, zur Passivität geschwungen durch Verrat des Wortes von der Rechtfertigung allein aus Gnade an den kirchlichen homo faber". In die hermeneutiese wisselwerking tussen die normatiewe en die konkrete werklikheid kan God en sy Woord tot passiwiteit gedwing word en selfs gestol word. Dan kom die inkleding van die werklikheid neer op dit wat die mens in sy vaardigheid kan laat realiseer en verander. As voorbeeld van hierdie denke kan verwys word na die "Pastoral counseling"-beweging waarin die instaatstellingsfaktor sentraal staan: iemand moet gehelp word om homself te help deur 'n groter insig in sy innerlike konflikte te verkry, sodat hy van negatiewe kragte en vermoëns binne-in homself losgemaak kan word (vgl. Hiltner, 1949:19). Met hierdie benadering word baie klem gelê op die menslike vermoëns wat in die pastorale beraad ontsluit moet word (vgl. Van Heerden, 1996:22). Die gevaar word geloop om ' $n$ vergoddeliking van menslike moontlikhede te probeer aktiveer, omdat die mens as betroubaar beskou word; iemand met 
onbegrensde moontlikhede om sy eie selfaktualisering te bewerkstellig (Houtsma,1983:88).

\subsection{Die mens se dade word losgemaak van die dade van Christus}

Hierdie probleem het ook ten diepste te doen met 'n praktiesteologiese Pneumatologie waarin die mens en sy geloof en sy dade en die manier waarop die Gees hom lei, losgemaak word van, of relatief selfstandig gemaak word ten opsigte van die Christologiese faset daarvan. Wanneer Christus slegs 'n moontlikheid bied tot versoening met God, vind 'n verskuiwing plaas waarby die swaartepunt nie meer lê op wat Hy doen nie, maar op wat mense doen. Die geloof verander ook van aard. Geloof is dan nie meer louter reseptief ten opsigte van die heil in Christus nie, maar dit verkry 'n kreatiewe funksie om potensiële heil te transponeer na effektiewe heil (vgl. Van Pelt, 1999:211).

\subsection{Om onder leiding van die Gees deur Christus se oë te kyk}

In die gang van hierdie artikel word gepoog om Skriftuurlike merkers te identifiseer vir die ontwerp van 'n prakties-teologiese Pneumatologie waarin die een werklikheid waarvan in sowel die teologiesnormatiewe dimensie asook in die konkrete praksis sprake is, as eenheid tot sy reg kom: So 'n eenheid impliseer 'n Pneumatologie waarin lyne tussen die onsigbare en die sigbare, die potensialiteit en die realisering daarvan, konsekwent nie as stippellyn nie, maar as 'n soliede lyn getrek word. Of - om dit in die woorde van Pieterse (1990:51) te stel - in so 'n eenheid word die plek van die Gees in die prakties-teologiese handelingsteorie getipeer as dié van 'n Brugbouer. Binne so 'n Pneumatologie kyk die mens onder leiding van die Gees deur die oë van Christus na die werklikheid; deur die genade van God en in die versoenende krag van Christus alleen word nuwe dade uitgevoer in die konkrete werklikheid van die kerk as verbondsgemeenskap. Die implikasies van die lyne wat in hierdie Pneumatologie getrek word, word toegepas op twee praktiesteologiese begrippe:

\section{- Versoening as die wesenlike van prakties-teologiese handelinge}

Eerstens kom versoening as die wesenlike van die handelinge wat deur Praktiese Teologie ondersoek word, ter sprake. Daar word gepoog om aan te dui dat versoening nie tot 'n teologies-abstrakte konsep begrens kan word nie, maar deurbreek in die konkrete werklikheid en alles nuutmaak. (Versoening is 'n sentrale begrip in 
die prakties-teologiese denke van C.J.H. Venter. Venter was vir die skrywer van hierdie artikel 'n jarelange mentor en het die oë oopgemaak vir die wesenlike plek van versoening in praktiesteologiese handelinge.)

\section{- Pneumatologiese implikasies vir waarneming as sleutel- begrip}

Tweedens word die pneumatologiese implikasies vir waarneming as sleutelbegrip aangedui. Deur middel van verruimde geloofswaarneming word nie alleen perspektiewe oopgemaak oor hoe normatiewe en onsigbare faktore lewend verbind is aan die konkrete, sigbare dimensie van werklikheid nie, maar word ook 'n nuwe handelingsgerigtheid ontsluit, waarin al die eer aan God gegee word.

\section{2. 'n Prakties-teologiese Pneumatologie waarin die eenheid tussen die normatiewe en die praksis tot sy reg kom}

Louw (1999:93) besef dat Pneumatologie 'n integrale faktor is in die kontinuïteit tussen die konkrete aardse werklikheid waarin die mens hom bevind en die kragte van die toekomstige bedeling wat van Godsweë nou reeds vernuwend werksaam is:

The pneumatological point of contact for an encounter between God and the human spirit is significant. It indicates that the continuity between the earthly and the eschatological life is not situated in inner psychic abilities, but only in the faithfulness of God and his transforming actions through the renewing power of the process of change and growth.

Wanneer die pneumatologiese lyn afgebreek of tot 'n stippellyn vervaag in die hermeneutiese wisselwerking tussen die normatiewe en die praksis, loop teologie die gevaar om in abstrakte, werklikheidsvreemde teorie op te gaan. Die rigtende effek van normatiewe teologie blyk dan geen effek op die sigbare praksis te hê nie en daar word ook nie verwag dat dit enige verskil kan maak nie. Dan word 'n vrugbare teelaarde geskep vir prakties-teologiese denke waarin sterk gefokus word op 'n positivistiese analise van die empiriese werklikheid. Ook val die klem dan op die soeke na handelingsmoontlikhede en die aankweek van tegniese vaardighede wat kan lei tot 'n meer effektiewe funksionering van die praksis. Binne so 'n teologie word die metafisiese op die agtergrond verskuif, omdat dit geassosieer word met 'n statiese teologie wat geen verband met die eksistensiële probleme van mense het nie. Die 
genoegsaamheid van die Woord as enigste ware openbaringsbron word aangetas. Teologie verander in antropologie - die skepsel in plaas van die Skepper word dan die hoogste verwysingspunt vir werklikheidsgetroue waarneming (Hielema, 1975:242).

Hielema (1975:64) toon aan hoe die denke van Hiltner neig tot operasionalisme, funksionalisme en pragmatisme; 'n denke wat deur Hiltner self as "operation-centered" getipeer word en waarvolgens die betekenis van 'n saak slegs waarlik vasgestel kan word op grond van 'n waarneming van die manier waarop dit funksioneer. Crabb (1987:93) toon aan hoe 'n pragmatiese swaartepunt in die denke daartoe aanleiding gee dat Skrifbeginsels gerelativeer kan word:

Rather than concerning ourselves with truth based on Scripture, we use whatever procedure seems right to us according to the pragmatic criterion: Does it work? We assume that truth represents that synthesis of all competing ideas which seems to best fit the current situation. The absolutes of Scripture become flexible limits which can be bent to accommodate our understanding of what appears most workable.

Wanneer denke 'n funksionalistiese en pragmatistiese swaartepunt toon, impliseer dit dat die mens dinge moet laat gebeur. Al word daar begin met Gees, word in eie krag geëindig.

\subsection{Van Ruler en die begrip teonome resiprositeit}

In 'n poging om die geheim van die verhouding tussen die Goddelike Gees en die menslike gees te omskryf en daarmee die onsigbare dimensie van die Goddelike werklikheid met die sigbare dimensie van die mens en sy konkrete handelinge in kontinuïteit te bring, ontwerp Van Ruler (1969:181) die begrip teonome resiprositeit: Dit wat in Christologie plaasvervanging heet, heet in Pneumatologie resiprositeit. Die mens laat hom vervang; hy laat die Middelaar in sy plek staan en hom vervang. Resiprositeit laat die mens ontdek dat die Gees alles gee en doen. Die Gees sit die mens aan die werk. Rebel (1981:248) werk die prakties-teologiese implikasies van Van Ruler se Pneumatologie uit. Teenoor die psigoterapeutiese kliëntgesentreerde en verhouding-gesentreerde pastoraat van Hiltner (met Tillich daaragter) en die kerugmaties Christosentriese benadering van Thurneysen (met Barth daaragter) ontwerp hy 'n pneumatiese pastorant-sentraalstellende pastoraat (vanuit die teologiese denke van Van Ruler). In die Pneumatologie kom dit daarop neer dat die mens, deur die inwoning van die Gees in hom, homself is en bly. Die mens is en bly iemand wat in kreatiwiteit, mondigheid en selfbewussyn optree, sonder dat in humanisme 
verval word. Die mens kom vrywillig en op grond van sy eie insig tot oortuiging van die waarheid en die bewys van die heil van God in Christus en die verhouding tussen God en mens wat daarby hoort (Rebel, 1982:157; vgl. Van Pelt, 1999:260). Die outonomiteit van die mens word in hierdie pneumatologiese denke sterk beklemtoon. Die mens met sy outonomiteit kan die outoriteit van God nie aantas nie, net soos die goddelike outoriteit menslike outonomiteit nie ondermyn nie. Die hele saak van God word in die hande van die mens (in pneumatologiese konteks) gelê en word sodoende ook die saak van die mens. Op hierdie manier verkry die pastoraat 'n antroposentriese aard, waarin die herstel en ontwikkeling van die mens 'n volle plek verkry (vgl. Dingemans, 1996:85). Hierdie pneumatologiese denke van Rebel (in navolging van Van Ruler) maak die pneumatologiese kategorie relatief selfstandig ten opsigte van die Christologiese kategorie. Die Christologiese kategorie word eensydig net geassosieer met die God-in-Christus-verhouding (vgl. Van Ruler, 1969:176), terwyl die implikasies van die Christus-in-onsen die ons-in-Christus-verhouding nie pneumatologies verantwoord word nie. In hierdie Pneumatologie staan die instaatstellingsfaktor sentraal. Die mens is vry om kreatief en innoverend op te tree. Maar kan hierdie kreatiwiteit en innovering een oomblik losgemaak word van God se genade in Christus? Kan een prakties-teologiese tree gegee word sonder dat dit in die krag van Christus gegee word? In 'n Pneumatologie wat losgemaak word van Christus, is dit nie meer Christus wat in my lewe nie, maar ek wat in my lewe.

\subsection{Die verhouding tussen Christologie en Pneumatologie}

Ten einde te verseker dat daar nie in die krag van die Gees begin word en in eie krag geëindig word nie, is dit nodig om die verhouding Christologie-Pneumatologie prakties-teologies te verantwoord. Louw (1999:104) wys daarop dat 'n antropologie wat geanker is in Christologie sonder die Heilige Gees, kan ontwikkel in 'n evolusionele model wat gebaseer is op die self-aktualiserende beginsel. Mense ontwikkel hulle verlossing uit hulle eie potensiaal en op grond van die ontiese relasie tussen hulle eie menslikheid en die menslikheid van Christus. Die vleeswording dien dan as 'n kontakpunt tussen God en ons menslikheid en nie langer meer as 'n openbaring van God se identifisering met menslike nood nie. Christus word dan 'n ideaal of model (tipologie) vir perfekte menslikheid. Hy funksioneer dan nie meer as Middelaar tussen God en 'n mens, iemand wat versoening tussen die twee bewerk nie (vgl. Louw, 1999:69). In 'n Geeslose Christologiese prakties-teologiese benadering word die evangelie tot 'n objek verlaag wat die mens 
behulpsaam kan wees in die uitwerk van metodes, tegnieke en die slyp van vaardigheid (vgl. Hielema, 1975:263). Sonder die regte verhouding tussen Christologie en Pneumatologie verstar teologie aan die een kant tot kraglose, simboliese en relatiewe beginsels wat die ideaal slegs as voorbeeld kan voorhou. Aan die ander kant word die praksis verhef tot fenomenologiese empirie waarin menslike potensiaal en vryheid tot kragtige ontplooiing kom.

\subsection{Die verbondskonsep in die Pneumatologie}

In 'n Bybels-Reformatoriese inkleding van Pneumatologie word die verhouding tussen die Goddelike Gees en die menslike gees geplaas in die konteks van die verbond. In die verbond bewerk Christus as Verbondsmiddelaar ' $n$ versoende verhouding met God en word die mens deur die Gees gelei om deur geloof in Christus voluit in hierdie herstelde verhouding te lewe. Die verbondskonsep laat nie alleen reg geskied aan die tema van die Here se vrye genade in die heilsgeskiedenis nie, maar skep ook ruimte vir die mens in die heilswerk van God (Van Wyk, 2003:4). In Vos en Pieterse (1992:149) se kommunikatiewe handelingsteorie dryf verbond as konsep nie rond tussen ander teologiese konsepte nie, maar word dit hanteer as 'n sentrale begrip ten opsigte van herstelde kommunikasie en herstelde verhoudings.

Jonker (1982:30) wys daarop dat die antropologie van die Reformasie gestempel word deur die spesifiek-Reformatoriese belydenis insake die verlossingsweg, naamlik dat die mens geregverdig word deur die geloof alleen. Die sola gratia, sola fidei, solus Christus van die Reformatoriese soteriologie is alles-bepalend vir die wyse waarop oor die mens gedink word. Die solas impliseer dat die beslissende dinge wat oor die mens gesê kan word, nie betrekking het op iets wat hy in homself het nie, maar dat dit betrekking het op Gods genadedaad aan hom, die vryspraak oor die mens as sondaar. Die primêre taak van die Gees (vgl. Joh. 14:26; $16: 13-15)$ is om die gelowige se denke op Christus te rig. Daar is nooit iets nuuts in blote menslike ervaring nie, maar daar is altyd iets nuuts in Christus, wanneer sy Woord ingewortel word in die hart en deel word van die ervaring van die nuwe mens. In die nuwe verbond is daar 'n onlosmaaklike verhouding tussen Christus wat opgestaan het uit die dood en die lewendmakende Gees wat mense laat deel in hierdie nuwe opstandingslewe (Zoutendijk, 2004:259). 


\subsection{Deur die verbond is God en mens blywend by mekaar betrokke}

Eerder as om die verhouding tussen die Gees en mens as teonome resiprositeit te kwalifiseer (waarin die selfstandigheid van Gees in die Triniteit beklemtoon word en die pneumatologiese kategorie nie konsekwent terugherlei word na Christologie nie), kan aansluiting gevind word by die denklyn van Van Pelt (1999:272) wat hierdie verhouding as foederatiewe (verbondsmatige) parallelisme kwalifiseer. God en mens is verskillend van mekaar en staan teenoor mekaar (paralleliteit), maar is by wyse van die verbond blywend op mekaar betrokke (die foederatiewe aspek).

Die uitgangspunt vir die keuse van die begrip parallelisme is die besef van die verskil tussen God en mens. In die spreke van die Bybel oor God val dit op hoe Hy as Skepper absoluut verhewe is bo sy skepping en hoe Hy as Verlosser en Vernuwer vir mense onnavolgbaar is in sy doen. Dit bring mee dat die parallelisme asimmetries gestruktureer is. Die verbond waarvan sprake is in hierdie asimmetriese verhoudingstruktuur is monopleuries in sy ontstaan (die aktiwiteit gaan van een party uit, naamlik van God), maar is dupleuries in werking (vgl. Van Wyk, 2003:19). Nie die wederkerigheid van die verbond nie, maar die soewereiniteit van God se genade staan in die Bybel voorop (Gen. 17:7; 2 Kor. 6:6; Heb. 8:10). Met dupleuriese werking word nie gelykheid of gelykwaardigheid bedoel nie, maar die aanduiding daarvan dat die verbond bestem is om in die krag van die Heilige Gees deur die mens bewus en vrywillig aanvaar te word. Die vergoddeliking van die humanum en vermensliking van die divimum word in hierdie karakteristieke verbondsverhouding uitgesluit.

In die konteks van 'n verbond wat 'n dupleuriese werking het, word prakties-teologiese handelinge wat gerig is op houdings- en handelingsveranderinge nooit dwangmatig en outomatisties ingeklee nie. Binne die konteks van die verbond hou prakties-teologiese handelinge rekening daarmee dat die mens waarop die handelinge gerig is, gewillig sy geloofstoestemming gee (Vos, 1996:149). In die dupleuriese werking van die verbond is daar nie sprake van die gees van vrees, waardeur iemand weer onder 'n slawejuk ingedwing word nie, maar dit is die Gees van kindskap wat hier aan die werk is. God gee die genade om aan sy eise te gehoorsaam en sy heerskappy te aanvaar (Van Wyk, 2003:19).

Christus is die Middelaar van die verbond. Deur sy kragtige optrede as Middelaar word die weg gebaan vir mense wat in Hom ingelyf is 
deur ware geloof om onder leiding van die Gees in alle opsigte gewillig as nuwe mense te lewe: met 'n verhelderde verstand, met 'n geopende hart, met 'n nuwe wil wat lieflik genees en oopgebuig is in God se diens (vgl. Dordtse Leerreëls, 3/4:11).

\subsection{Die dupleuriese werking van die verbond en ortognosie}

In die dupleuriese werking van die verbond kom die mens se gesindheid, denke en optrede onder leiding van die Gees altyd in die vorm van geloof na vore. Jonker (1974:205-207) gebruik die woord ortognosie om die vermiste skakel tussen ortodoksie (die regte leer) en ortopraksis (die regte daad) aan te dui. Ortognosie dui die regte kennis van God, die innerlike gesindheid van geloof aan. Ortognosties word die onsienlike gesien in die sigbare praksis. Eers wanneer die gelowige oortuig is dat die dinge wat nie gesien kan word nie, 'n lewende werklikheid is en dat sy sigbare bestaan ingebed is in hierdie lewende werklikheid, kan daar sprake wees van ortognosie. Nie alleen die konkrete gestalte van die liggaam van Christus word gesien soos dit in intermenslike verhoudinge na vore kom nie, maar ook die onsigbare Hoof wat organies en lewend by sy kerk teenwoordig is. Daar word nie vasgekyk teen die onmoontlikheid van praksis wat onherstelbaar verbrokkel het nie, maar in geloof word vasgehou aan die wete dat by God niks onmoontlik is nie. Die ortopraksis word in hierdie onmoontlike situasie ingeklee in dade wat van lewende hoop getuig. Geloof is en bly diep geanker in Christus. Die Gees verbind die gelowiges aan die Vader "op de wijze van de Zoon" en "dankzij de Zoon" (Zoutendijk, 2004:257).

Die Gees lei die gelowige om deur die oë van Christus na die werklikheid te kyk: So 'n visie vervul die waarnemer met liefde en innige jammerte vir mense in nood wat lei weens die gebrek aan versoening. So 'n visie vervul die waarnemer egter ook met heilige toorn vir die onhoudbare praksis van onversoenlikheid. Crabb (1987:98) vat dit wat met ortognosie bedoel word, treffend saam wanneer hy sê:

Skinner renews circumstances. Rogers renews feelings. Glasser renews behaviour. Analysts renew the personality. Christ renews minds. The basis of all transformation is to think differently, to believe differently, to change basic assumptions.

Gedagtes wat vernuwe is, lei tot nuwe dade. Die Gees lei die gelowige om met vrymoedigheid in die krag van Christus se versoeningswerk op te tree. Die potensialiteit van die nuwe mens lê daarin dat hy deur Christus in staat gestel word tot alles; sy 
kreatiwiteit lê daarin dat hy onder die Hoofskap staan van die Een wat sê: Kyk, ek maak alles nuut!

\section{Die wesenlike plek van geloof en versoening in prakties-teologiese pneumatologiese denke}

\subsection{Versoening as die sentrale inhoud van die Skrif}

Venter (1976:19) verbind die handelinge waarvan daar in Praktiese Teologie sprake is (in prediking, kategese, pastoraat, liturgiek) met dit wat hy as die sentrale inhoud van die Skrif beskou, naamlik versoening. Christus se versoeningswerk, soos dit tot openbaring kom in sy koms, opstanding en hemelvaart, is die hart van die Bybel (Venter, 1991:57). Versteeg (1989:31) kom teen die agtergrond van die $\mathrm{Ou}$ en Nuwe Testament tot 'n kernagtige tipering van twee aspekte van die een werklikheid van versoening.

- Eerstens dui die een werklikheid van versoening op die bymekaarbring van twee partye wat teenoor mekaar staan (die inhoudelike kant van versoening soos dit deur die woord katallagé verwoord word).

- Tweedens dui versoening op die gee van 'n offer tot bedekking van die skuld (die wyse waarop versoening tot stand kom soos dit in die woord hilasmos verwoord word).

Wanneer versoening die grondbeginsel is waarop Praktiese Teologie en alle handelinge wat daaruit voortvloei, gebou is, sal die inhoudelike van Praktiese Teologie en die doel waarop alle handelinge afgestuur word, ook opgaan in die bymekaarbring van partye (God en mens op vertikale vlak en mens en mens op horisontale vlak). Die belangrikste vraag in die metodologie van die Praktiese Teologie sal dan die vraag wees na die wyse waarop deel gekry kan word aan die versoening en die lewensvernuwing en lewensvolheid wat daaruit voortvloei. Praktiese Teologie sal homself van begin tot einde diensbaar stel in die bediening van versoening. In 2 Korintiërs 5:20 word die proses van versoening in Christus met formele pastorale optrede verbind. Christus se werk van versoening is die vertrekpunt en voleindigingspunt waarop alle praktiesteologiese handelinge gerig is. In die konteks van die gemeente trek die roeping van die bedienaar van die Woord saam in die bediening van God se versoening in Christus aan die gemeente (Venter, 2004:433).

Venter (1976:38) lei uit 2 Korintiërs 5:17 af dat versoening 'n allesomvattende nuwe bedeling inlei. As iemand in Christus is, is hy ' $n$ 
nuwe skepsel: die ou dinge het verbygegaan; alles het nuut geword. In die nuwe, eskatologiese bedeling bepaal versoening die gedrag, optrede en verhoudinge van die gemeente. Hierdie versoening kan nie alleen toepaslik wees vir ' $n$ bepaalde periode of begrens word tot 'n bepaalde groep mense nie, maar dit is allesbepalend vir die voleindiging waarop die hele wêreld besig is om op af te stuur.

In prakties-teologies pneumatologiese denke sal die versoening in Christus 'n sentrale plek inneem. Die versoening wat deur Christus bewerk is en waarvan die verbondsgemeenskap van die kerk bedienaars is, sal die inhoud van die volle waarheid wees waarin die Gees ons lei (Joh. 16:13). In geloof sal onder leiding van die Gees gesien kan word dat herstelde verhoudinge op intermenslike vlak alleen kan voortvloei uit 'n herstelde verhouding met God op grond van die versoeningswerk in Christus. Die nuwe waarna gestrewe word in die handelingspraksis, sal nooit vernuwing ter wille van vernuwing wees, of vernuwing wat kunsmatig nuwe asem in 'n "dooie" praksis wil blaas nie (vgl. De Wet \& Venter, 1998:141). Die nuwe waarna gestreef word, sal aangepak word in die geloof dat daar waar Christus se versoeningswerk bedien word, alles nuut word - 'n nuutheid wat sy voleindiging vind in niks minder as ' $n$ nuwe hemel en 'n nuwe aarde nie.

\subsection{Versoening as voldoening en heilstoe-eiening}

Wat die wyse waarop versoening bewerk word betref, vind Van Pelt (1999:210) die hart van die manier waarop versoening bewerk word in die voldoenende werk van Christus. Hiermee sluit hy bewustelik aan by die klassieke opvatting omtrent die Bybelse leer van versoening deur voldoening (satisfactio vicaria). Die versoening vind plaas deur Christus wat ons menslike natuur verenig met sy goddelike natuur en sodoende as Middelaar tussen God en die mense staan. Versoening is nie ' $n$ handeling wat slegs van buite af op die mens afkom nie, maar is 'n daad van God wat mens geword het (representasie), en daarom 'n daad wat uitgevoer is in die plek van die mens en ten behoewe van die mens (plaasvervanging) (2 Kor. 5:21; Gal. 3:13). Hierdie wyse waarop versoening in Christus bewerk word, vra 'n besondere inkleding van die prakties-teologiese bediening van versoening. Daar kan nie van die vertrekpunt uitgegaan word dat die moontlikheid van heil van God se kant gegee is en dat die verwerkliking en belewing van heil 'n saak van die mens is nie. Wanneer Christus slegs 'n moontlikheid bied tot versoening met God, vind 'n verskuiwing plaas waarby die swaartepunt nie meer lê op wat Hy doen nie, maar op wat mense doen. Die geloof verander ook van aard. Die geloof is nie meer 
louter reseptief ten opsigte van die heil in Christus nie, maar dit verkry 'n kreatiewe funksie om potensiële heil te transponeer na effektiewe heil (Van Pelt, 1999:211).

Hierdie manier van dink oor heilstoe-eiening stel die mens in staat om self - met pastorale begeleiding - die greep van skuld en skuldgevoelens te breek en 'n nuwe lewe te skep deur kreatiewe denke. Brillenburg Wurth (1955:46) verwys na die taal van die hedendaagse mens waarin versoening geklee word en die implikasies wat daaruit voortvloei: Daar word nie meer gepraat van bekering nie, maar van lewensvernuwing; nie van geloof nie, maar van oorgawe; nie van die gebooie van God nie, maar van die eise van absolute waarheid, eerlikheid en liefde. Binne so 'n beklemtoning neem Christus 'n totaal ander plek in as in die evangelie. Hy word meer beskou as die voorbeeld of bron van sedelike krag as die beginsel van die versoening van sondes. Wanneer hierdie weg opgegaan word, vervul Praktiese Teologie nie meer die nederige dienskneggestalte van bedienaar van versoening nie, maar eien dit vir homself die reg toe om bewerker van versoening te word.

\subsection{Die bron van versoening is Christus}

In verbondskonteks laat die praktiese teoloog hom deur die Gees in die volle waarheid lei om die Bron van versoening alleen in die volbringende werk van die Verbondsmiddelaar, Jesus Christus, te soek en in die geloof te wag op die ware herstel wat deur Hom alleen gegee kan word. Die Praktiese Teologie kan die woord van versoening slegs bedienend plant en natgooi, maar dit is slegs God wat kan laat groei. Die versoening kan nie bewerk word nie, maar alleen bedien word (Venter, 1976:38). Nederigheid sal derhalwe 'n belangrike grondhouding van die praktiese teoloog wees. Sy bediening sal van begin tot einde deur gebed omraam word. In nederige afhanklikheid sal hy bid dat sy geestesoë verhelder sal word om te sien hoe geweldig groot God se krag is wat Hy uitoefen in die mense wat glo; dieselfde kragtige werking van sy mag wat $\mathrm{Hy}$ uitgeoefen het toe Hy Christus uit die dood opgewek en Hom in die hemel aan sy regterhand laat sit het (vgl. Ef. 1:19, 20).

\section{Die plek van gelowige waarneming as sleutelbegrip in prakties-teologiese pneumatologiese denke}

Waarneming is 'n sleutelbegrip in praktiese teologie. In die hermeneutiese wisselwerking tussen normatiewe en konkrete praksis vervul waarneming ' $n$ onmisbare funksie ten opsigte van die 
kontinuïteit en waarheids- en werklikheidsgetrouheid. Dit is op grond van waarneming dat 'n praktiese teoloog tot nuwe perspektiewe kom en nuwe perspektiewe vir ander oopgesluit kan word. "Theologie kommt von der Wahrnehmung her und bereitet Wahrnehmung vor" (Bohren; 1979:15). Eers wanneer iemand die werklikheid in 'n nuwe lig gesien het, kan handelinge ontsluit word wat waarlik nuut is. In sy pneumatologiese benadering tot Praktiese Teologie definieer Bohren (1975:135) waarneming as 'n begrip met 'n dubbele dimensie waarin die eenheid tussen teorie en praksis op 'n organiese manier tot uitdrukking kom. Waarneming het nie alleen te doen met die sien van die aangrypende visie wat God vir sy gemeente en die wêreld het nie, maar ook met die waarneem van geleenthede waarin hierdie nuwe visie tot sy reg kom in die praksis van die gemeente.

In die oorgaan van die teologiese visie wat waargeneem geword na die waarneem daarvan in die konkrete praksis, is 'n verantwoorde Pneumatologie van begin tot einde van wesenlike belang. Sonder die Heilige Gees word die onmoontlike taak aangepak om geestelike dinge met vleeslike sintuie te wil waarneem. Niemand kan die verborge dinge van God sien, behalwe die Gees van God nie. Dit is slegs deur die Gees wat uit God kom, dat ons kan weet wat God ons uit genade geskenk het (1 Kor. 2:11, 12).

Bohren (1996:79) laat hom deur Calvyn se uitleg van 2 Korintiërs 4:18 lei om die oë van die geloof te sien as 'n waarnemingsintuig wat verder dring as die natuurlike sintuie (vgl. Calvyn, 1976:65). Die primêre sig het sy wese in die aanskoue van die onsigbare en word vervul met verwondering oor die verrassend nuwe wat gevind word. Hierdie verrassende nuwe kom nie tot stand op grond van menslike sienvermoë nie, maar bestaan uit 'n waarnemingskerpte wat alleen verleen kan word deur die Een wat ons toegerus het om dienaars van die nuwe verbond te word, nie van die letter nie, maar van die Gees (vgl. Rom. 7:6).

Slegs deur die geloof en dan bepaald deur geloof in Jesus Christus kan die geestelike dinge van God gesien word en die volle rykdom van dit wat God ons uit genade geskenk het, waargeneem word. Deur Jesus Christus word die hemelse dimensie oopgemaak sodat die Vader gesien kan word:

Ek is die weg en die waarheid en die lewe. Niemand kom na die Vader toe behalwe deur My nie. As julle My ken, sal julle my Vader ook ken. En van nou af ken julle Hom en sien julle Hom (Joh. 14:6; vgl. 1:18; 12:44-46). 


\subsection{Verruimde geloofsinsig}

Deur geloof in Jesus Christus vind daar 'n verruiming in die waarnemingsveld plaas sodat die hemelse dimensie (bepaald kennis van die Vader), toeganklik word (vgl. Venter \& De Wet, 1999:488 e.v.). In die geloofsverhouding met Jesus Christus, die Middelaar van die nuwe verbond, word die nuwe mens daartoe gebring om met dieselfde verwondering na die Vader en sy wil te kyk, as dit wat teenwoordig was in Christus, toe van Hom gesê is dat die liefde vir die huis van sy Vader Hom verteer het. Die Gees van Christus gee die verruimde geloofsinsig om die dinge van die Vader deur die oë van Christus te sien. Ook in die waarneem van geleenthede in die handelingspraksis van die verbondsruimte, word in die gees en die gesindheid opgetree van Hom wat sê: "Kyk, Ek maak alles nuut."

\subsection{Waarneming is nie 'n menslik geïnisieerde bewus- wordingsproses nie}

Sonder hierdie Christusverankerde Pneumatologie in verbondskonteks verwater die gebruik van waarneming as sleutelbegrip in prakties-teologiese handelinge tot die toepassing van kommunikatiewe tegnieke om te oortuig en tot verandering te motiveer. Die omvangwydte van waarneming word begrens tot 'n tegniese handeling waarin inkomende stimulus-inligting so verwerk word dat daar tot aktiewe, bewuste aandag gekom word. Waarneming kan dan begrens word tot 'n eendimensionele proses wat deur verskillende fases van meeluistering, spontane perseptuele organisering, spontane konseptuele kategorisering verloop totdat daar by aktiewe, bewuste aandag gekom word (vgl. Vos, 1996:213). Van geloof en geloofstoe-eiening in dupleuriese verbondskonteks is daar dan geen sprake nie.

Selfs wanneer die dimensie van die geloof in waarneming verreken word - maar op so 'n wyse dat dit losgemaak word van dit wat Christus gedoen het en deur sy Gees steeds doen - kan die waarnemingsproses ontaard in 'n menslik geïnisieerde bewuswordingsproses. In die pastoraat van Zijlstra (1989:283) word geloof en waarneming geplaas in 'n kategorie van 'n geleidelike bewuswordingsproses waarin die mens al groeiende sy bestemming bereik. Hierdie uitspraak kan volgens Van Pelt (1999:42) waar wees in die wêreld van dieptepsigologie, maar dit kan nie waar wees ten opsigte van geloof nie. Is die weg van bewuswording - as die weg van die mens tot God se menslikheid as sy eindbestemming dieselfde as die weg van die geloof in Jesus Christus? Kan oor die 
geloof gepraat word as 'n groeiproses van bewuswording en individualisasie (selfontdekking)? Bybels-teologies gesien (volgens Van Pelt, 1999:42), is dit 'n onhoudbare situasie. In die Bybel word gepraat oor verandering in terme van roeping, wedergeboorte, geloof en bekering (Joh. 3:3; Hand. 9; 1 Pet. 1:3). Daar is geen sprake van 'n langsame verhelderende proses waardeur innerlike groeikragte in die mens geaktiveer word nie.

\subsection{Verandering impliseer 'n radikaal ingrypende gebeure}

Verandering gaan om radikaal ingrypende gebeure by 'n mens wat met verwondering konstateer dat iets beslissend in hom gebeur. Ontwikkeling en bewuswording is woorde wat geleidelikheid suggereer. Dit veronderstel dat daar iets in die mens aanwesig is wat alleen nog verder ontwikkel moet word. Verandering in die Bybelse sin van bekering is iets anders. In bekering gaan dit om 'n breuk met die bestaande, om die werk van die Gees. Wanneer geloof en bewuswording vermeng word, word geloof gereduseer tot 'n beskeie impuls in 'n psigologiese proses.

\section{Samevatting}

- In die ondersoekveld van Praktiese Teologie kom twee dimensies van een werklikheid ter sprake: die onsigbare dimensie van God se normatiewe, versoenende en voleindigende handelinge én die sigbare dimensie van die konkrete handelingspraksis van die kerk op pad na 'n nuwe hemel en aarde.

- Sonder 'n verantwoorde Pneumatologie loop Praktiese Teologie die gevaar om in sy teorievorming wel in die Gees te begin, maar in eie krag te eindig. Al word daar met die Gees begin, kan 'n gebrekkige Pneumatologie daartoe aanleiding gee dat die Gees as die Gees wat ons inlei in die volle waarheid van Christus se heilswerk - se teenwoordigheid en kragtige optrede tot stippellyne vervaag namate die dimensie van die sigbare en konkrete werklikheid in die hermeneutiese wisselwerking betree word. Daar kan basisteoreties in die Gees begin word, maar dit wat uiteindelik in die konkrete werklikheid van praktykteorie uitkristalliseer, kan dan in niks anders opgaan as 'n openbaring van eie krag, kreatiwiteit en innovering nie.

- In 'n Skrifgefundeerde prakties-teologiese Pneumatologie word God se handelinge en die mens se handelinge en die manier waarop hierdie onderskeie handelinge op mekaar betrekking het, geplaas in die werklikheidsomvattende ruimte van die verbond - 
die verbond waarin Jesus Christus as Verbondsmiddelaar optree in die realisering van 'n herstelde verhouding tussen God en mens en mense onderling. Hierdie optrede van Christus lei tot 'n handelingspraksis waarin alles waarlik nuut gemaak word. In die konteks van hierdie verbond met 'n monopleuriese ontstaan en 'n dupleuriese uitwerking word die nuwe mens deur die Gees gelei om sy lewe en handelingspraksis gelowig in die krag en gesindheid van Christus te anker.

- Die wesenlike handeling, waaruit alle prakties-teologiese handelinge gebore en die gerigtheid daarvan bepaal word, is versoening. Praktiese Teologie is bediening van versoening. In 'n onverantwoorde Pneumatologie word versoening losgemaak uit die Skriftuurlike lewensbodem van die verbond en die sentrale optrede van die Verbondsmiddelaar. Christus bied dan slegs ' $n$ moontlikheid tot versoening met God. 'n Onverantwoorde, ankerlose Pneumatologie stel die mens dan in staat om deur kreatiwiteit (wat in die plek van geloof in Christus kom) sy eie heil uit te werk en van homself ' $n$ beter mens te maak wat meer effektief funksioneer. In 'n Pneumatologie wat geanker is in verbondskonteks, sien die gelowige dat 'n nuwe lewe en herstelde verhoudinge alleen kan voortvloei uit 'n herstelde verhouding met God op grond van die versoeningswerk in Christus. In nederige afhanklikheid word erken dat ons nie bewerkers nie, maar slegs bedienaars van die versoening kan wees.

- Waarneming is 'n sleutelbegrip in Praktiese teologie. In die hermeneutiese wisselwerking tussen normatiewe en konkrete praksis vervul waarneming 'n onmisbare funksie ten opsigte van kontinuïteit en waarheids- en werklikheidsgetrouheid. In die oorgaan van die teologiese visie van wat waargeneem geword na die waarneem daarvan in die konkrete praksis, is geloof in Jesus Christus van wesenlike belang. In 'n onverantwoorde Pneumatologie word die mens in staat gestel om deur bewuswording 'n nuwe visie op die kerk te ontwikkel en om innoverend nuwe handelingsmoontlikhede toe te pas. Die onmoontlike taak word aangepak om geestelike dinge met vleeslike oë te wil waarneem. Wie deur vleeslike oë na die werklikheid kyk, se handelingsmoonlikhede word tot die vlees beperk. En alles wat uit die vlees kom, is verganklik en loop op niks blywends uit nie. Die enigste oë waardeur die werklikheid in die onsigbare en sigbare dimensie daarvan gesien kan word, is deur die oë van Jesus Christus. In die geloof lei die Gees die mens om deur die oë van Christus te 
kyk. Dan eers kan 'n mens sien wat die ontsaglike dimensies van die hoogte en die diepte en wydte is wat God ons uit genade skenk. Vanuit hierdie verruimde geloofswaarneming kan geleenthede waargeneem word in die krag van Hom wat sê: "Kyk, ek maak alles nuut".

\section{Geraadpleegde bronne}

BOHREN, R. 1975. Daß Gott schön werde: Praktische Theologie als theologische Ästhetik. München: Kaiser.

BOHREN, R. 1979. Geist und Gericht: Arbeiten zur Praktischen Theologie. Neukirchen: Neukirchener Verlag.

BOHREN, R. 1996. Praktische Theologie als Wissenschaftskritik: Anmerkungen zu Günter Grass: "Über das Sekundäre aus primäre Sicht”. (In Möller, C. \& Ehmann, R., Red. Predigen aus Leidenschaft: Homiletische Beiträge für Rudolf Bohren zum 75. Geburtstag. Karlsruhe: Verlag Evangelischer Presseverband für Baden e.V. p. 79-102.)

BRILLENBURG WURTH, G. 1955. Christelijke zielsorg in het licht der moderne Psychologie. Kampen: Kok.

CALVYN, J. 1976. Calvin's Commentaries: The second epistle of Paul the apostle to the Corinthians and the Epistles to Timothy, Titus and Philemon. Grand Rapids: Eerdmans.

CRABB, L.J. 1987. Basic Biblical counseling. (In Benner, D.G., ed. Christian counseling and psychotherapy. Grand Rapids: Baker. p. 91-103.)

DE WET, F.W. \& VENTER, C.J.H. 1998. Die implikasies van enkele pneumatologiese insigte van Rudolf Bohren vir die Praktiese Teologie. In die Skriflig, 32 (2):127-143.

DINGEMANS, G.D.J. 1996. Manieren van doen: Inleiding tot de studie van de Praktische Theologie. Kampen: Kok.

DREYER, J.S. 2002. Theological normativity: Ideology or utopia? Reflections on the possible contribution of empirical research. Praktiese Teologie in SuidAfrika, 17(2):1-20.

HEITINK. G. 1999. Practical Theology. Grand Rapids: Eerdmans.

HIELEMA, J.S. 1975. Pastoral or Christian counseling. Leeuwarden: De Tille.

HILTNER, S. 1949. Pastoral counseling. New York: Abingdon-Cokesbury.

HOUTSMA, R. 1983. De groep als pastorale weg. 's-Gravenhage: Boekencentrum.

IMMINK, F.G. 2003. In God geloven: Een praktisch-theologische reconstructie. Zoetermeer: Meinema.

JONKER, H. 1974. "Orthognosie". Theologia Reformata, 17(3):205-207.

JONKER, W.D. 1982. Antropologie en soteriologie. Skrif en Kerk, 3(2):29-41.

KRUGER, S.F. \& VENTER, C.J.H. 2001. Die verhouding tussen Psigologie en Praktiese Teologie: aspekte van die onderlinge waarde van dié verhouding. In die Skriflig, 35(4):557-573.

LANDAU, R. 1981. "Komm, Heiliger Geist, du Tröster wert ...": Gestaltungen des Heiligen Geistes. Evangelische Theologie, 41 (3):187-211.

LOUW, D.J. 1999. A mature faith: Spiritual direction and anthropology in a theology of pastoral care and counseling. Louvain: Peeters. 
PIETERSE, H.J.C. 1990. Practical Theology as a theological operational science. (In Heyns, L.M. \& Pieterse, H.J.C., ed. A primer in Practical Theology. Pretoria: Gnosis. p. 46-56.)

PIETERSE, H.J.C. 1993. Die probleem van normatiwiteit en rasionaliteit in die beoefening van praktiese teologie. Praktiese Teologie in Suid-Afrika, 8(2):197-203.

PIETERSE, H.J.C. 2005. Hoe kom God aan die woord in die prediking? Die probleemstelling. Praktiese Teologie in Suid-Afrika, 20(1):77-95.

REBEL, J.J. 1981. Pastoraat in Pneumatologisch perspektief: een theologische verantwoording vanuit het denken van A.A. van Ruler. Kampen: Kok.

REBEL, J.J. 1982. Pneumatologie en pastoraat. Theologia Reformata, 25(3): 155-169.

VAN HEERDEN, P.R. 1996. Heilsrealisering in 'n narratiewe diakonale pastoraat. Bloemfontein: Universiteit van die Oranje Vrystaat. (Ph.D.proefskrif.)

VAN PELT, J.W. 1999. Pastoraat in trinitarisch perspectief: die samehang tussen trinitarische en antropologische aspecten in het pastoraat. Heerenveen: Groen.

VAN RULER, A.A. 1969. Theologisch werk. Deel 1. Nijkerk: Callenbach.

VAN WYK, J.H. 2003. Teologie van die verbond of teologie van die koninkryk? Dogmatiese nadenke oor die verhouding tussen die verbond en die koninkryk as sentrale teologiese temas. In die Skriflig, 37(1):1-26.

VENTER, C.J.H. 1976. Die bediening van die versoening aan die bejaarde: ' $n$ pastorale studie in die lig van die Pastorale Briewe. Potchefstroom: PU vir CHO. (Th.D.-proefskrif.)

VENTER, C.J.H. 1991. Guidelines for the praxis of pastoral counseling. The Journal of Pastoral Care,10(3):55-62.

VENTER, C.J.H. 1996. Uitkringende liefdesbetoon: Kommunikatiewe handelinge in diens van die onderlinge liefdesgemeenskap in die kerk. Pretoria: RGN.

VENTER, C.J.H. 2004. Die prediker wat houe uitdeel: die gemeente as teiken. In die Skriflig, 38(3):429-449.

VENTER, C.J.H \& DE WET, F.W. 1999. 'n Teologies-estetiese benadering tot Praktiese Teologie: homiletiese implikasies vir Christene ten opsigte van hulle taak in 'n gebroke samelewing. Skrif en Kerk, 20(2):482 499.

VERSTEEG, J.P. 1989. Bijbelwoorden op de man af. Kampen: Kok.

VOS, C.J.A. 1996. Die volheid daarvan I: Homiletiek uit 'n hermeneutieskommunikatiewe perspektief. Pretoria: RGN.

VOS, C.J.A \& PIETERSE, H.J.C. 1992. Antropologiese insigte binne die kommunikatiewe handelingsteoretiese benadering in die Praktiese Teologie. Praktiese Teologie in Suid-Afrika, 7(2):147-158.

ZIJLSTRA, W. 1989. Op zoek naar een nieuwe horizon: Handboek voor klinische pastorale vorming. Nijkerk: Callenbach.

ZOUTENDIJK, A.J. 2004. De identiteit van de Heilige Geest volgens de Brieven van Paulus. Theologia Reformata, 47(3):248-272. 
Kernbegrippe:

geloof en versoening, wesenlike plek van gelowige waarneming as sleutelbegrip normatiewe en praksis: eenheid tussen prakties-teologiese Pneumatologie

\section{Key concepts:}

faith and reconciliation, the essential place of norm and praxis; unity between perception through faith as key concept practical-theological Pneumatology 
